\title{
AGEING, ARTERIAL BLOOD PRESSURE, BODY MASS INDEX, AND DIET
}

\author{
Mladen PAVLOVIĆ ${ }^{1}$, Sanja MILKOVIĆ-KRAUS ${ }^{1}$, Veljko JOVANOVIĆ2 , and Mira \\ HERCIGONJA-SZEKERES ${ }^{3}$
}

Institute for Medical Research and Occupational Health, Zagreb ${ }^{1}$, Retired scientific adviser ${ }^{2}$, Hrvatsko Zagorje Polytechnics, Krapina ${ }^{3}$, Croatia

Received in October 2011

CrossChecked in April 2012

Accepted in April 2012

\begin{abstract}
For three decades we followed up for longevity indicators, including diet, arterial blood pressure, and body mass index 379 mobile, long-living persons from Croatia, now aged 70 to 92 years, of whom 167 men aged (78.6 \pm 4.0$)$ years and 212 women aged (77.9 \pm 4.1$)$ years. One hundred and ninety-five were from the continental and 184 from the coastal Croatia. The participants were examined in 1972, 1982, and again in 2006/7. Changes in body mass index (BMI), arterial blood pressure (ABP), and in answers to our Food Frequency Questionnaire about dietary habits were analysed using log-linear models. Over the last 24 years of aging (age 55 to 78 years) the subjects showed a statistically significant decrease in body mass and height and a significant increase in the systolic blood pressure. Diastolic blood pressure and BMI showed no significant changes over this period. Consumption of preserved and fresh meat, bread, and starch (potato, pastry and rice) dropped significantly with age, while the consumption of fish, fresh and cooked vegetables, fruit, and dairy products significantly increased. These dietary changes were not associated with changes in the systolic and diastolic ABP. About $80 \%$ were overweight (BMI $>25 \mathrm{~kg}$ $\mathrm{m}^{-2}$ ) throughout the follow-up, even though their body mass dropped significantly after the age of 55 . However, their survival suggests that BMI may not be the best indicator of longevity or healthy aging.
\end{abstract}

KEY WORDS: follow-up, food frequency questionnaire, healthy ageing, longevity, mobile elderly

In developed nations ageing is associated with the remarkably increasing lifespan at a constant rate, suggesting that there is no natural limit on life expectancy. Similarly, life expectancy in Croatia has been increasing about 2.3 months per year since 1961 (1).

When longevity is analysed for more than three decades, as in the present study, one approach is to document lifestyle (including socioeconomic status and dietary habits), place of residence, and sex (27).

Natural selection determines how organisms adapt as they grow old. It is believed that food intake has an important role (8). So far, our follow-up study, which began in 1972, has confirmed that dietary habits have a role in the survival rate of a population, complemented by a variety of local lifestyle and cultural characteristics, which seem to differ between the continental and coastal Croatia. This influence of diet and lifestyle on ageing reflects itself in Adolphe Quételet's Body Mass Index (BMI) and arterial blood pressure (ABP) in free-living elderly populations (9-11).

The aim of this follow-up was to document dietary habits estimated through a simple Food Frequency Questionnaire $\left(\mathrm{FFQ}_{\mathrm{IMI}}\right)$ and $\mathrm{BMI}$ as risk factors that can affect $\mathrm{ABP}$ and survival. 


\section{SUBJECTS AND METHODS}

\section{Study participants}

The study sample was selected from the 1968 electoral register and included volunteers from the continental (City of Zagreb, District of Virovitica) and coastal Croatia (Split, Island of Vis, District of Omišs) who were examined in 1972, 1982, and 2006. The first examination included 3212 free-living subjects, the second 2415, and the third 379 (of 907 invited).

\section{Methods}

At each examination we collected dietary data using our own Food Frequency Questionnaire $\left(\mathrm{FFQ}_{\mathrm{IMI}}\right)$, then data on arterial systolic and diastolic blood pressure, and BMI. Data collection, $\mathrm{FFQ}_{\mathrm{IMI}}$ interviews, and $\mathrm{ABP}$ measurements were done by experienced, well-trained specialists in internal medicine. At the 1982 and 2006 examinations we used the same method as in 1972, described elsewhere (12).

\section{Food frequency questionnaire}

$\mathrm{FFQ}_{\mathrm{IMI}}$ was designed in 1972 and revised in 1982 by the Department of General and Clinical Medicine of the Institute for Medical Research and Occupational Health, Zagreb in collaboration with Andrija Stampar School of Public Health, Zagreb University. Data collected were validated by medical experts in 1972 and 1982 (13-15). The participants had to score from one to five the consumption of ten food groups*: preserved meat, fresh meat, fish (mainly pelagic), cooked vegetables, fresh fruit and vegetables, legumes, potatoes, pastry and rice, cookies and sweets, bread, and dairy products. $\mathrm{FFQ}_{\mathrm{IMI}}$ is a simple questionnaire based on the past month's diet over the same season.

\section{Anthropometry and blood pressure measurement}

Body mass was measured using a calibrated Korona scale (Brest, Germany). Body height was measured in a standing position without shoes, with

\footnotetext{
* 1 - the participant does not consume this food group at all

2 - the participant consumes this food group up to three times a month

3 - the participant consumes this food group once a week

4 - the participant consumes this food group two to three times a week

5 - the participant consumes this food group almost every day

Bread: $1=$ none; $2=1$ slice a day; $3=2$ to 3 slices a day; $4=4$ to 5 slices a day; $5=5$ or more slices a day

Dairy products: $1=$ never; $2=$ occasionally; $3=$ often; $4=$ every day a little; $5=$ every day a lot
}

the head positioned in the Frankfort horizontal line, and measurements were taken using a tailor's tape. Body height and body mass were measured according to the International Biological Program (16). BMI was calculated as the ratio between body mass $(\mathrm{kg})$ and squared height $\left(\mathrm{m}^{2}\right)$.

Systolic and diastolic ABP were taken with a mercury sphygmomanometer (Reister, Germany) following the routine standards after 10 minutes of rest. Table 1 shows the arbitrary criteria for normal, borderline, and high systolic and diastolic ABP and BMI.

\section{Statistical analysis}

For statistical analysis we used Statistica 6.0 (StatSoft Inc., Tulsa, OK, USA). We used descriptive statistics for subject groups, and the $t$-test to test the differences between parameters analysed from 1982 to 2006. Table 1 ranks the APB and BMI parameters as the first step to establishing patterns between physiological variables and the dietary data. The interaction between the variables was analysed using log-linear models. Log-linear analysis is a basic method for analysing categorical variables by cross-tabulation. The method is based on the estimation of discrepancies between the tables of fitted models (expected frequencies) and observed contingency tables. Log-linear models are commonly used to evaluate multi-way contingency tables that involve possible associations between three or more variables. Variables investigated by log-linear models are all treated as "response variables". In other words, no distinction is made between independent and presumed dependent variables.

The first model included the following variables for the follow-up periods 1972-1982 or 1982-2006: sex, residence, systolic blood pressure, diastolic blood pressure, and BMI. The second model included the following variables for the follow-up period 1982-2006: sex, residence, diet (by means of $\mathrm{FFQ}_{\mathrm{IMI}}$ ), and BMI. The third model (for the same period) included the following variables: sex,

Table 1 Ranking of systolic and diastolic blood pressure and body mass index

\begin{tabular}{lccc}
\hline & $\begin{array}{c}\text { Diastolic BP / } \\
\mathbf{m m ~ H g}\end{array}$ & $\begin{array}{c}\text { Systolic BP } \\
/ \mathbf{m m ~ H g}\end{array}$ & $\begin{array}{c}\text { BMI / } \\
\mathbf{k g ~ m}^{-2}\end{array}$ \\
\hline Elevated & $\geq 100$ & $\geq 160$ & $\geq 30$ \\
\hline Borderline & 90 to 99 & 140 to 159 & $\begin{array}{c}25 \text { to } \\
29.9\end{array}$ \\
\hline Normal & $<89$ & $<139$ & $<25$ \\
\hline
\end{tabular}

Legend: BP-blood pressure; BMI- body mass index 
residence, systolic or diastolic blood pressure, diet $\left(\mathrm{FFQ}_{\mathrm{IMI}}\right)$, and $\mathrm{BMI}$. We estimated partial and marginal correlations. The statistical significance of associations was assessed according to Pearson and/or G-estimator as the sum of partial maximum likelihoods, as follows:

$$
\text { chi square }\left(g_{\mathrm{ijk}}\right): g_{\mathrm{ijk}}=2 \mathrm{f}_{\mathrm{ijk}} \ln \left(\mathrm{f}_{\mathrm{ijk}} / \mathrm{F}_{\mathrm{ijk}}\right) \text {, }
$$

where $F_{i j k}$ denotes the fitted or expected frequency and $\mathrm{f}_{\mathrm{ijk}}$ is the observed frequency. Statistical significance was set at $p<0.05$. We used Bishop's coefficient (chi square) ${ }^{1 / 2}$ and Freeman-Tukey assessment of parameter significance.

\section{RESULTS}

Table 2 shows mean values of the analysed parameters over the three follow-up periods (1972, 1982, and 2006), separated by sex and residence.

Table 3 shows differences $(\Delta)$ between the analysed parameters recorded for all included subjects in 1982 and 2006. Over the 24 years of aging, body mass and height significantly dropped, and the systolic blood pressure rose. The diastolic blood pressure and BMI showed no significant changes. The consumption of preserved and fresh meat, bread, and starch (potato, pastry and rice) also dropped significantly with years. At the same time the consumption of fish, fresh and cooked vegetables, fruit and dairy products significantly increased. The consumption of legumes and sweets remained about the same.

Interactions between aging, blood pressure BMI, and diet

Figure 1 shows log-linear interactions between the age of 45 to 55 (1972 to 1982), residence, sex, systolic and diastolic blood pressure, and BMI. Interactions between variables show that BMI and systolic and diastolic blood pressure significantly rose from the age of 45 to 55 years. The BMI increase was independent of the subjects' residence, but was more pronounced in women. BMI also positively correlated with the systolic and diastolic blood pressure. Regardless of the correlation between APB and $\mathrm{BMI}$, systolic and diastolic blood pressure were mutually significantly dependent. Increases in diastolic pressure were associated with residence and sex, showing greater increase in women and subjects from the continental Croatia.

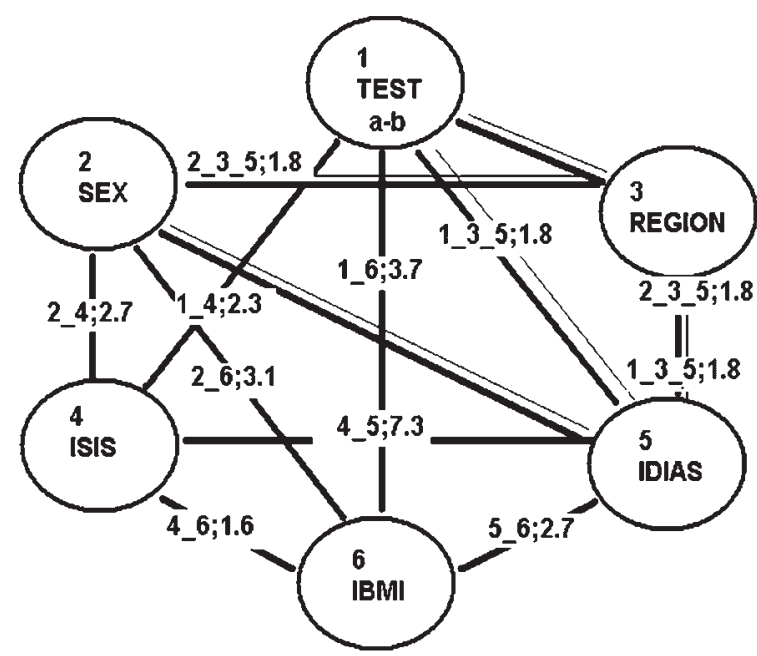

Figure 1 Log-linear model for interactions between aging from 1972 to 1982 (TEST $a$-b), residence (REGION), sex, systolic (ISIS) and diastolic (IDIAS) blood pressure, and body mass index (IBMI).

Lines denote significant correlations between individual variables. Double lines denote correlations between three parameters. Each association is marked by figures. The first 2 or 3 figures refer to the associated variables. The last figure refers to the strength of the relationship between the variables.

Figure 2 shows log-linear interactions between the age of 55 to 78 (1982 to 2006), residence, sex, systolic and diastolic blood pressure, and BMI. BMI

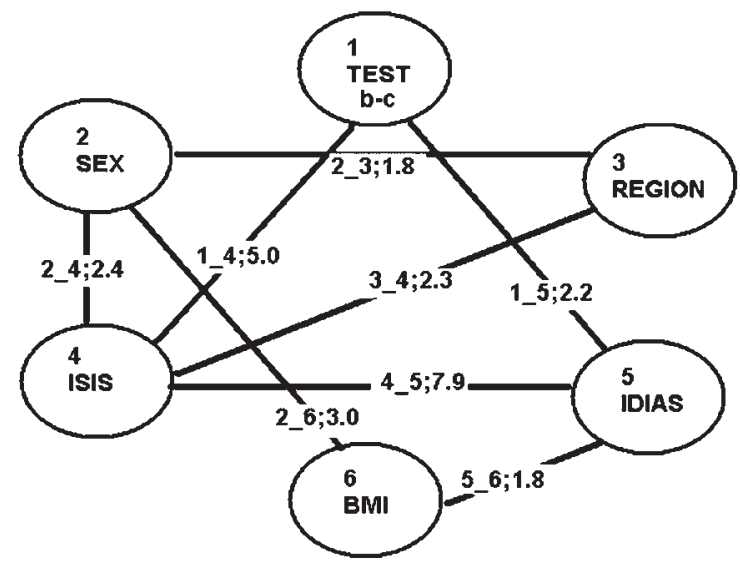

Figure 2 Log-linear model for interactions between aging from 1982 to 2006 (TEST b-c), residence (REGION), sex, systolic (ISIS) and diastolic (IDIAS) blood pressure, and body mass index (IBMI).

Lines denote significant correlations between individual variables. Double lines denote correlations between three parameters. Each association is marked by figures. The first 2 or 3 figures refer to the associated variables. The last figure refers to the strength of the relationship between the variables. 
Table 2 Age, body mass, arterial blood pressure, and body mass index (chi square $\pm S D$ ) in 1972, 1982, and 2006 in the same study participants $(N=379)$ by sex and residence (coastal and continental Croatia)

\begin{tabular}{|c|c|c|c|c|c|c|c|}
\hline $\begin{array}{l}\text { Number of } \\
\text { participants }\end{array}$ & $\begin{array}{c}\text { Year of } \\
\text { follow-up }\end{array}$ & Age / years & Height / cm & Mass / kg & $\begin{array}{c}\text { Systolic } \\
\text { pressure / } \\
\text { mm Hg }\end{array}$ & $\begin{array}{c}\text { Diastolic } \\
\text { pressure / } \\
\text { mm Hg }\end{array}$ & $\begin{array}{l}\mathrm{BMI} / \\
\mathrm{kg} \mathrm{m}^{-2}\end{array}$ \\
\hline \multicolumn{8}{|c|}{ Men (coastal Croatia) } \\
\hline 90 & 1972 & $44.6 \pm 4.8$ & $175.8 \pm 6.3$ & $81.8 \pm 9.8$ & $136 \pm 17$ & $86.7 \pm 9.0$ & $26.4 \pm 2.8$ \\
\hline 90 & 1982 & $54.6 \pm 4.8$ & $174.4 \pm 6.0$ & $85.3 \pm 10.4$ & $137 \pm 19$ & $84.5 \pm 12$ & $28.0 \pm 3.0$ \\
\hline 90 & 2006 & $78.6 \pm 4.8$ & $172.0 \pm 5.9$ & $83.9 \pm 10.8$ & $151 \pm 19$ & $88.7 \pm 10.4$ & $28.3 \pm 3.2$ \\
\hline \multicolumn{8}{|c|}{ Women (coastal Croatia) } \\
\hline 94 & 1972 & $43.9 \pm 4.8$ & $163.1 \pm 5.6$ & $72.5 \pm 9.3$ & $138 \pm 15$ & $87.1 \pm 8.9$ & $27.3 \pm 3.5$ \\
\hline 94 & 1982 & $53.9 \pm 4.8$ & $161.9 \pm 5.4$ & $75.8 \pm 9.6$ & $146 \pm 20$ & $88.1 \pm 10.8$ & $29.0 \pm 3.5$ \\
\hline 94 & 2006 & $77.9 \pm 4.8$ & $159.5 \pm 5.9$ & $74.2 \pm 10.7$ & $158 \pm 20$ & $89.9 \pm 9.5$ & $29.2 \pm 4.0$ \\
\hline \multicolumn{8}{|c|}{ Men (continental Croatia) } \\
\hline 77 & 1972 & $44.1 \pm 4.0$ & $172.3 \pm 5.8$ & $77.3 \pm 10.2$ & $133 \pm 13$ & $86.4 \pm 9.1$ & $26.0 \pm 2.8$ \\
\hline 77 & 1982 & $54.1 \pm 3.96$ & $171.0 \pm 5.7$ & $79.7 \pm 10.0$ & $136 \pm 14$ & $86.9 \pm 9.6$ & $27.2 \pm 2.9$ \\
\hline 77 & 2006 & $78.1 \pm 4.0$ & $169.8 \pm 5.7$ & $79.0 \pm 11.5$ & $144 \pm 16$ & $86.8 \pm 9.0$ & $27.4 \pm 3.5$ \\
\hline \multicolumn{8}{|c|}{ Women (continental Croatia) } \\
\hline 118 & 1972 & $43.4 \pm 4.1$ & $160.4 \pm 6.5$ & $67.4 \pm 10.8$ & $134 \pm 13$ & $83.5 \pm 10$ & $26.2 \pm 3.7$ \\
\hline 118 & 1982 & $53.4 \pm 4.07$ & $158.6 \pm 6.4$ & $71.4 \pm 12.3$ & $145 \pm 20$ & $88.2 \pm 10.3$ & $28.3 \pm 4.3$ \\
\hline 118 & 2006 & $77.4 \pm 4.1$ & $156.5 \pm 6.6$ & $70.5 \pm 12.3$ & $147 \pm 17$ & $86.7 \pm 8.7$ & $28.7 \pm 4.4$ \\
\hline
\end{tabular}

Table 3 Changes in dietary habits, systolic and diastolic arterial blood pressure, and body mass index from 1982 to 2006

\begin{tabular}{|c|c|c|c|c|}
\hline Variable & $\begin{array}{c}\text { Arithmetic } \\
\text { mean }\end{array}$ & Standard deviation & $t$-test & p-value \\
\hline$\Delta$-SIS & 8.6284 & 24.97 & 6.29 & $<0.05$ \\
\hline$\Delta$-DIAS & 0.9698 & 13.29 & 1.33 & NS \\
\hline$\triangle$-PRESERVED MEAT & -0.26 & 1.28 & -3.7 & $<0.05$ \\
\hline$\Delta$-FRESH MEAT & -0.36 & 1.15 & -5.75 & $<0.05$ \\
\hline$\Delta$-FISH & 0.43 & 1.28 & 6.07 & $<0.05$ \\
\hline$\triangle$-COOKED VEGETABLES & 0.38 & 1.30 & 5.29 & $<0.05$ \\
\hline $\begin{array}{l}\Delta \text {-FRESH FRUIT AND } \\
\text { VEGETABLES }\end{array}$ & 0.49 & 1.21 & 7.38 & $<0.05$ \\
\hline$\Delta$-LEGUMES & 0.04 & 1.31 & 0.50 & NS \\
\hline $\begin{array}{l}\Delta \text {-STARCH } \\
\text { POTATO, PASTRY AND RICE }\end{array}$ & -0.61 & 1.09 & -10.12 & $<0.05$ \\
\hline $\begin{array}{l}\Delta \text {-SWEETS } \\
\text { AND COOKIES }\end{array}$ & -0.15 & 1.41 & -1.96 & NS \\
\hline$\Delta$-BREAD & -0.61 & 1.20 & -9.28 & $<0.05$ \\
\hline$\Delta$-DAIRY PRODUCTS & 0.18 & 1.44 & 2.22 & $<0.05$ \\
\hline$\Delta$-HEIGHT / cm & -2.47 & 2.12 & -20.5 & $<0.05$ \\
\hline$\Delta$-BODY MASS / kg & -1.15 & 9.15 & -2.43 & $<0.05$ \\
\hline$\Delta-\mathrm{BMI} / \mathrm{kg} \mathrm{m}^{-2}$ & 0.29 & 3.30 & -1.67 & NS \\
\hline
\end{tabular}

4- Difference between mean values from all included subjects in 1982 and 2006 
no longer increased. However, systolic blood pressure did increase. Beside the association between systolic and diastolic blood pressure, systolic pressure showed an association with sex and residence, with more pronounced increase in men and subjects from the coastal Croatia.

Interactions between ageing from 1982 to 2006, residence, sex, diet $\left(\mathrm{FFQ}_{\mathrm{IMI}}\right)$, and $\mathrm{BMI}$ confirmed the significant association between BMI and sex. Almost all $\mathrm{FFQ}_{\mathrm{IMI}}$ dietary habits (except sweets and cookies) changed with age (Table 3 ).

Significant associations were found between residence and the consumption of preserved meat, fish, legumes, starch, sweets, bread, and dairy products, but this association was especially pronounced in the consumption of fish. Continental consumption of fish was significantly below the average and the coastal consumption was above the average.

The statistical power of the two additional loglinear models was also estimated. These models included the interactions between ageing in the period 1982 to 2006, residence, sex, dietary habits $\left(\mathrm{FFQ}_{\mathrm{IMI}}\right)$ systolic and diastolic blood pressure, and BMI. Model estimates showed that dietary habits were not associated with systolic and diastolic blood pressure.

\section{DISCUSSION AND CONCLUSIONS}

To the best of our knowledge, this is the first follow-up cohort study of correlations between dietary habits, $\mathrm{ABP}$, and BMI in Croatia, and we found only one similar reference in PubMed, but with different population structure (19).

We observed significant changes in ABP and BMI with age, but they differed between the sexes and the ageing period. Between the ages of 45 and 55 years increases in $\mathrm{ABP}$ and $\mathrm{BMI}$ were more pronounced in women than in men, perhaps due to hormonal changes (the beginning of the menopause). Between the ages of 55 and 78 years, this increase in ABP and BMI was halted, with the exception of the significant increase in systolic blood pressure in men, which could be related to andropause. In this period, dietary habits also changed, as the consumption of meat, bread and starch (potato, pastry and rice) dropped, and the consumption of fish, fresh and cooked vegetables, fruit and dairy products increased with age. These changes could be at least partly responsible for the maintenance of BMI.
It is believed that passive salt intake is associated with the development of arterial hypertension and cardiovascular mortality (19-21). However, these studies have not confirmed the association between dietary changes and changes in ABP.

Body mass started to significantly drop after the age of 55 . However, about $80 \%$ of our participants, as a representative sample of mobile, long-living population of Croatia, were overweight according to the WHO BMI classification $\left(25 \mathrm{~kg} \mathrm{~m}^{-2}\right.$ to 29.9 $\mathrm{kg} \mathrm{m}^{-2}$ ), which suggests that BMI has little or no influence on long and healthy ageing and is perhaps not the best indicator of longevity. This requires further investigation of the role of malnutrition in groups with the signs of frailty and sarcopenia and of the "obesity paradox" $(22,23-26)$.

\section{Acknowledgement}

This study was supported by the Croatian Ministry of Science, Education and Sports (grant no. 0220222411-2407).

\section{REFERENCES}

1. Andrija Štampar Zagreb Institute of Public Health, Center of Gerontology. Gerontological and public health indicators. In: Tomek Roksandić S, editor. Annual Report for 2002/3. Zagreb: URIHO; 2004.

2. Antal M, Regöly-Mérei A. [Nutrition and life style in the elderly-risk factors and recommendations, in Hungarian]. Orv Hetil 2011;152:182-9.

3. Pavlović M, Lauri-Koralija A, Šimić D, Bobić J, Čorović N. Percepcija zdravlja u pokretnih starijih osoba (segment studije o kroničnim bolestima u Hrvatskoj) [Perception of health among the mobile aged population (part of the study on chronic disease in Croatia), in Croatian]. Druš Istraž 2010;19:1079- 92.

4. Pavlović M, Šimić D, Čorović N. Perospektivna studija o učestalosti kroničnih bolesti u populaciji Hrvatske I zdravom starenju [Follow-up study on Chronic diseases in croatian population and healthy ageing, in Croatian]. HČJZ 2009;18:13.

5. Pavlović M, Čorović N. An overview of the 1969-2007 follow-up study of chronic diseases and healthy ageing in Croatia and pertinent publications. Arh Hig Rada Toksikol 2009;60:61-8.

6. Hayflick L. Entropy explains aging, genetic determinism explains longevity, and undefined terminology explains misunderstanding both. PLoS Genet 2007;3(12):e220. doi: 10.1371/ journal.pgen.0030220.

7. Ham JR, Sloane PD, Warshaw GA. Primary care geriatrics: a case based approach. $4^{\text {th }}$ ed. St. Louis (MO): Mosby Inc.; 2001.

8. Burke MM, Laramie JA. Epidemiology of aging: the older population in the United States. In: Burke MM, Laramie JA, 
editors. Primary care of the older adult: a multidisciplinary approach. $2^{\text {nd }}$ ed. St. Louis (MO): Mosby Inc.; 2004. p. 62945.

9. McDonald RB, Ruhe RC. Aging and longevity: why knowing the difference is important to nutrition research. Nutrients 2011;3:274-82.

10. Bes-Rastrollo M, Perez JR, Sánchez-Villegas IP, Alonso A, Martínez-González MA. Validación del peso e índice de masa corporal auto-declarado de los participantes de una cohorte de graduados universitarios [Validation of self-reported weigh and body mass index in a cohort of university graduates, in Spain]. Rev Esp Obes 2005;3:352-8.

11. Mimica M, Rudan P, Malinar M, Pavlović M. Gojaznost, mršavost $i$ kronične bolesti u našoj populaciji [Obesity, leaness and chronic diseases in our population, in Croatian]. Acta Med Iug 1978; 32: 221-34.

12. Čerič B, Jurinović D, Pišl Z, Trinki M, Milković-Kraus S. Vpliv arterijske hipertenzije na smrtnost med prebivalstvom [Blood pressure influence on mortality in population, in Slovene]. Zdrav Vestn 1990;59: 309-11.

13. Jazbec A, Šimić D, Pavlović M, Malinar M. Influence of age, body mass index, smoking and alcohol intake on mortality in some regions in Croatia. In: Kalpić D and Hljuz Dobrić $\mathrm{V}$, editors. Proceeddings of the $21^{\text {st }}$ International Conference on Information Technology Interfaces - ITI'99; 15-18 June 1999; Pula, Croatia. p. 135-140.

14. Pavlović M. Do nutritional habits contribute to differences in adult cardiovascular mortality between the coastal and continental regions in Croatia? In: $4^{\text {th }}$ Nutrition and Health Conference; 21-22 Nov 2003; London, UK. Biographies \& Abstracts p. 46.

15. Lemkau PV, Kulčar Ž, Kesić B, Kovačić L. Selected aspects of the epidemiology of psychoses in Croatia, Yugoslavia. IV. Representative sample of Croatia and results of the survey. Am J Epidemiol 1980;112:661-74.

16. Weiner JS, Lourie JA. Practical Human Biology. New York (NY): Academic Press; 1981.
17. Missioni S. Nutritional studies in Croatia - a century of research. Coll Antropol 2006;30:673-96.

18. Musić Milanović S, Ivičević Uhernik A, Fišter K, Kovač A, Ivanković D. Five-year cumulative incidence of obesity in adults in Croatia: the CroHort study. Coll Antropol 2012;36(Suppl 1):71-6.

19. Zazpe I, Bes-Rastrollo M, Ruiz-Canela M, Sánchez-Villegas A, Serrano-Martínez M, Martínez-González MA.A brief assessment of eating habits and weight gain in a Mediterranean cohort. Br J Nutr 2011;20: 765-75.

20. He HJ, Burnier M, Macgregor GA. Nutrition in cardiovascular disease: salt in hypertension and heart failure. Eur Heart J 2011 Epub ahead of print.

21. Vranešić Bender D, Krznarić Ž, Reiner Ž, Tomek Roksandić S, Duraković Z, Kaić-Rak A, Smolej Narančić N, Bošnir J. Hrvatske smjernice za prehranu osoba starije dobi, dio I [Croatian guidelines for nutrition in the elderly, Part I, in Croatian]. Liječ Vjesn 2011;133:231-40.

22. Masanes F, Culla AS, Navarro-Gonzales M, Navarro-Kiopez M, Sacanella E, Torres B, Lopez-Soto A. Prevalence of sarcopenia in healthy community-dwelling elderly in an urban area of Barcelona (Spain). J Nutr Health Aging 2012;16: 184-7.

23. Casas-Vara A, Santolaria F, Fernández-Bereciartúa A, González-Reimers E, García-Ochoa A, Martínez-Riera A. The obesity paradox in elderly patients with heart failure: analysis of nutritional status. Nutrition 2012;dx.doi. org/10.1016/j.nutr 2011.10.006.

24. Bleich S, Cutler D, Murray C, Adams A. Why is the developed world obese? Annu Rev Public Health 2009;29:27395.

25. Ivančević Ž,urednik. MSD priručnik dijagnostike i terapije. II hrvatsko izdanje "Prehrana u kliničkoj medicini”. Split: Placebo; 2010. p. 6-14.

26. Kolčić I, Polašek $\mathrm{O}$, Vuletić $\mathrm{S}$. Scale and dynamics of overweight and obesity epidemic in Croatia. Obesity Facts 2010;3:333. 


\section{Sažetak}

\section{STARENJE, ARTERIJSKI KRVNI TLAK, INDEKS TJELESNE MASE I PREHRANA}

U radu se opisuje odnos promjena prehrambenih navika, indeksa tjelesne mase (ITM, engl. body mass index, krat. BMI) i arterijskoga krvnog tlaka tijekom praćenja starenja istih samostalnih, pokretnih ispitanika iz kontinentalne i priobalne regije Hrvatske u tridesetogodišnjem razdoblju. U 2006./2007. godini pregledan je uzorak od 379 osoba dobi 70 do 92 godine: 167 muškaraca dobi $(78,6 \pm 4,0)$ godine i 212 žena dobi $(77,9 \pm 4,1)$ godina, 195 rezidenata kontinentalne regije i 184 rezidenata iz priobalne regije. Ispitanici su pregledani po treći put u 2006. Bili su prethodno pregledani 1972. te ponovo 1982. godine, a s ciljem praćenja dugovječnosti u odnosu na način života, prehranu i spol. Pomoću log-linearne analize analizirali smo promjene ITM-a, arterijskoga krvnog tlaka i 10 kategorija prehrambenih namirnica. Pri tom smo koristili vlastiti Upitnik o prehrani: $\mathrm{FFQ}_{\mathrm{IMI}}$.

Kroz zadnje 24 godine praćenja starenja (dob 55 do 78 godina) nađeno je statistički značajno sniženje tjelesne mase i visine, te značajan porast sistoličkoga krvnog tlaka. Dijastolički krvni tlak i ITM nisu se značajnije mijenjali kroz ovo razdoblje. Rezultati pokazuju značajno smanjenje konzumiranja konzerviranoga i svježega mesa, kruha i škrobnih namirnica (krumpir, tjestenina, riža) sa starenjem, dok se konzumacija ribe, svježega i kuhanoga povrća, voća i mliječnih proizvoda povećala. Ove prehrambene promjene nisu bile povezane s promjenama arterijskoga krvnog tlaka. Iako je smanjenje tjelesne mase u naših ispitanika u dobi iznad 55 godina bilo značajno, oko 80 \% naših ispitanika, koje možemo smatrati reprezentativnim uzorkom pokretne, dugovječne populacije Hrvatske, pripadaju kategoriji osoba s prekomjernom tjelesnom masom (ITM $>25 \mathrm{~kg} \mathrm{~m}^{-2}$ ). Iz toga se može zaključiti da ITM nije dobar pokazatelj zdravog starenja i dugovječnosti.

KLJUČNE RIJEČI: dugovječnost, prehrana, starije pokretne osobe

\section{CORRESPONDING AUTHOR:}

\section{Mladen Pavlović}

Institute for Medical Research and Occupational Health

Ksaverska cesta 2, HR - 10000 Zagreb, Croatia

E-mail:mpavlov@imi.hr 